\title{
SIGNIFICANCE OF SACRAL INDEX IN ESTIMATION OF SEX OF SACRUM IN CENTRAL RAJASTHAN
}

\author{
William F. Masih1, Ashok Pratap Singh², Kunkbihari Rathore ${ }^{3}$
}

1 Professor, Department of Anatomy, Government Medical College, Kota, Rajasthan.

2Professor, Department of Anatomy, SRR Medical College, Mauritius.

3Senior Demonstrator, Department of Anatomy, Government Medical College, Kota, Rajasthan.

\section{ABSTRACT}

\section{BACKGROUND}

Anatomists, anthropologists and forensic experts judge the sex of the skeletal material by non-metric observations. Sex-dependent differences have been noted in the pelvic bone anatomy, and so differences exist in male and female sacrum. Over the years, different authors had carried various types of measurements on human sacra of different races. The well-known method for determination of sex of sacrum has always ideally been the Sacral Index method as explained in the Hrdlicka's Practical Anthropometry. The formula for Sacral Index is: Sacral Index = Width of Sacrum x 100/ Length of Sacrum.

The aim of this study was to collect data regarding morphometric measurements of maximum length and breadth of sacrum and to find out possible variations of sacral index in different individuals in relation to sex.

\section{MATERIALS AND METHODS}

A descriptive study was conducted in the Department of Anatomy, Govt. Medical College, Kota on 75 (seventy-five) adult human dry sacra of unknown sex. The sacral bones were distributed into male (40) and female (35) groups by discriminant functional analysis. The study sample was studied morphologically for sacral length and sacral breadth with digital sliding Vernier caliper.

\section{RESULTS}

The mean sacral index in male and female were $97.88 \pm 6.16 \%$ and $112.69 \pm 10.17 \%$ respectively. Female has the greater sacral index than male $(\mathrm{P}<0.001)$.

\section{CONCLUSION}

The bones of the body are the last to pass away after death, next to enamel of teeth. Medico-legal experts, anatomists and anthropologists use the skeletal materials for giving their opinion in respect to sex, age and stature for establishing the personal identity. Sacral index method is relevant and significant for determination of sex.

\section{KEYWORDS}

Discriminant Function Analysis, Gender, Sacral Index, Sex Determination, Sacrum.

HOW TO CITE THIS ARTICLE: Masih WF, Singh AP, Rathore K. Significance of sacral index in estimation of sex of sacrum in central Rajasthan. J. Evolution Med. Dent. Sci. 2017;6(64):4645-4648, DOI: 10.14260/Jemds/2017/1004

\begin{abstract}
BACKGROUND
Determination of sex is an integral part and first step in the development of the biological profile in human osteology. Establishing the identity of the human remains is one of the most important and challenging. Anatomical variations occur frequently in the lower region of the vertebral column making the sacrum the most variable portion of the vertebra. The variation may be attributed to the dependency of the final sacral morphology to the load-related fusion of the bony structures. Developmental malformation may occur as well. Forensic expert and anatomist have to give their opinion for the unknown and mutilated dead body. It was by Taylor in his book of medical jurisprudence that the accuracy of estimating the sex from skeletal remains depends upon number of bones available. ${ }^{1}$
\end{abstract}

Financial or Other, Competing Interest: None.

Submission 06-07-2017, Peer Review 31-07-2017,

Acceptance 05-08-2017, Published 10-08-2017.

Corresponding Author:

Dr. William F. Masih,

Professor,

Department of Anatomy,

Government Medical College,

Kota, Rajasthan.

E-mail: dr.williammasih@yahoo.com dr.williammasih1961@gmail.com

DOI: $10.14260 /$ jemds/2017/1004 
The aim of the present study is to determine the significance of sacral index in sex determination and compares the finding with different races according to the literatures available.

\section{MATERIALS AND METHODS}

A descriptive study was conducted in the Department of Anatomy, Govt. Medical College, Kota on 75 (seventy-five) adult human dry sacra of unknown sex. The sacral bones were distributed into male (40) and female (35) groups by discriminant functional analysis, i.e. is a statistical analysis to predict a categorical dependent). The study sample was studied morphologically for sacral length and sacral breadth with digital sliding Vernier caliper.

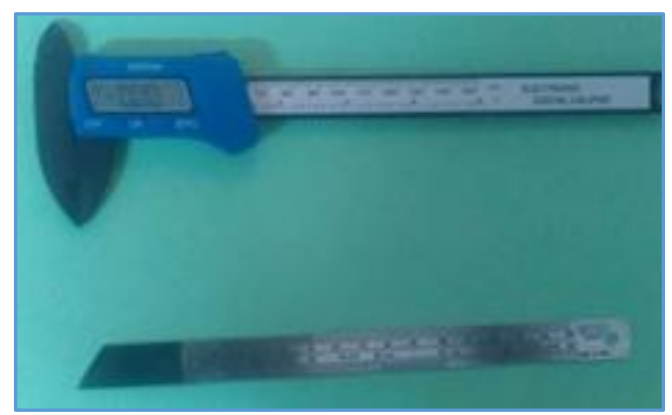

Figure 1. Digital Vernier Caliper

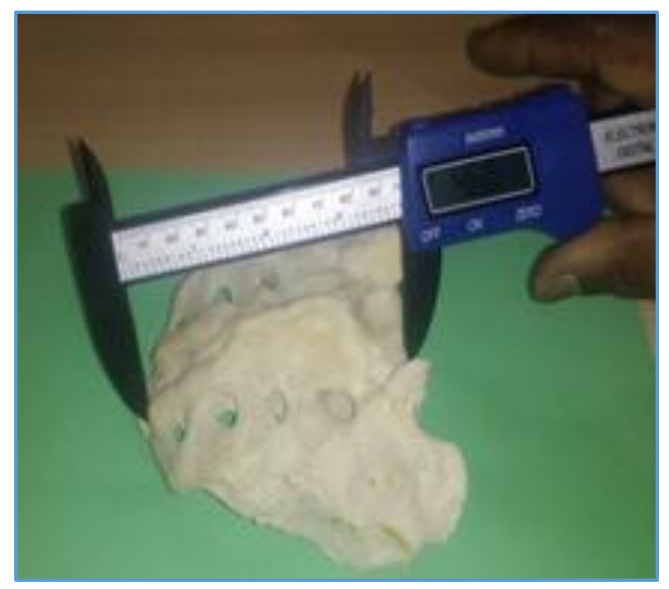

Figure 2. Measurement of Sacral Length with Digital Vernier Caliper

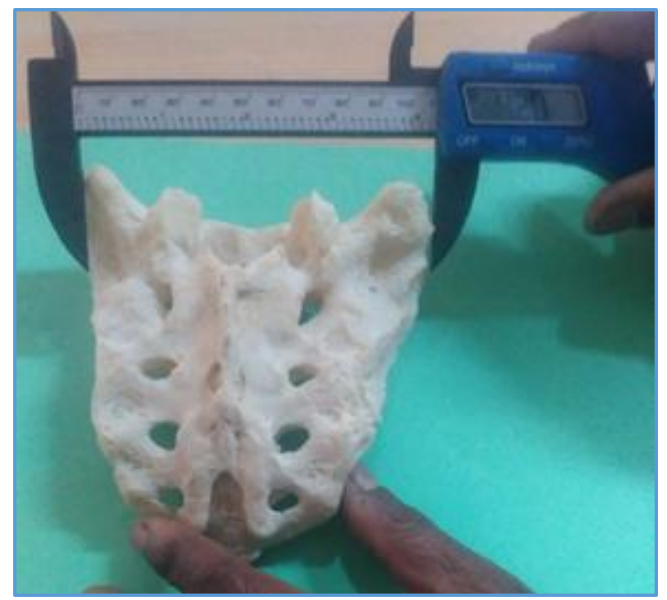

Figure 3. Measurement of Sacral Breadth with Digital Vernier Caliper
Sacral index was measured by taking the breadth and length of individual sacrum with the help of Vernier Digital Caliper and adopting the method as demonstrated in Hrdlicka's Practical Anthropometry.7,8 The stem of caliper was applied to upper surface of the body of first sacral vertebra and measurement of maximum breadth was taken across the greatest expanse of lateral masses of the bone as shown (Figure 1, 2 and 3).

A total of 75 (seventy-five) dried, completely ossified, grossly normal adult human sacra of unknown sex were assessed. The sacra were collected from Department of Anatomy of Govt. Medical College, Kota. The study samples were distributed in male and female sex groups by discriminant function analysis. With the help of digital Vernier calipers, different measurements were recorded in millimetres. Measurement of maximum length of sacrum was recorded by the distance from antero-superior margin of promontory to the middle of antero-inferior margin of the last sacral vertebra. Maximum breadth of sacrum was measured by taking two points at the upper part of auricular surface anteriorly.

The sacral index (SI) is calculated with the formula:

\section{Sacral Index $=$ Width of Sacrum $x$ 100 $/$ Length of Sacrum}

Differences between length and breadth done by paired student's ' $\mathrm{t}$ ' test and comparison between sex done by unpaired student's ' $\mathrm{t}$ ' test.

P-value $<0.05$ was considered statistically significant.

\section{Ethical Clearance}

This study was approved by the Ethical Review Committee of Govt. Medical College, Kota.

\section{RESULTS}

The mean length of sacrum in male and female was $107.44 \pm$ $6.95 \mathrm{~mm}$ and $91.65 \pm 7.03 \mathrm{~mm}$ respectively and the mean breadth of sacrum in male and female was $104.63 \pm 6.41 \mathrm{~mm}$ and $102.77 \pm 6.57 \mathrm{~mm}$ respectively. Sacral index in male and female is $97.88 \mathrm{SD} \pm 6.16$ and $112.69 \mathrm{SD} \pm 10.17 \%$ respectively.

In case male sacral length is greater than breadth and opposite was found in female i.e. breadth is greater than length $(\mathrm{P}<0.001)$ (Table 1$)$.

\begin{tabular}{|c|c|c|c|c|c|}
\hline $\begin{array}{c}\text { Sacral } \\
\text { Length } \\
\text { in Male } \\
\text { (MMS) }\end{array}$ & $\begin{array}{c}\text { Sacral } \\
\text { Breadth } \\
\text { in Male } \\
\text { (MMS) }\end{array}$ & $\begin{array}{c}\text { Sacral } \\
\text { Index in } \\
\text { Male }\end{array}$ & $\begin{array}{c}\text { Sacral } \\
\text { Length in } \\
\text { Female } \\
\text { (MMS) }\end{array}$ & $\begin{array}{c}\text { Sacral } \\
\text { Breadth } \\
\text { in Female } \\
\text { (MMS) }\end{array}$ & $\begin{array}{c}\text { Sacral } \\
\text { Index in } \\
\text { Female }\end{array}$ \\
\hline $\begin{array}{c}107.44 \\
\text { SD } \pm 6.95\end{array}$ & $\begin{array}{c}104.63 \\
\text { SD } \pm 6.41\end{array}$ & $\begin{array}{c}97.88 \\
\text { SD } \pm 6.16 \%\end{array}$ & $\begin{array}{c}91.65 \\
\text { SD } \pm 7.03\end{array}$ & $\begin{array}{c}102.77 \\
\text { SD } \pm 6.57 \%\end{array}$ & $\begin{array}{c}112.69 \\
\text { SD } \pm 10.17 \%\end{array}$ \\
\hline
\end{tabular}

Table 1. Length and Breadth of Sacrum in Male and Female

\begin{tabular}{|c|c|c|c|c|}
\hline & $\begin{array}{c}\text { Sacrum } \\
\text { Length }\end{array}$ & $\begin{array}{c}\text { Sacrum } \\
\text { Breadth }\end{array}$ & $\begin{array}{c}\text { Mean } \pm \text { SD } \\
\text { Value }\end{array}$ & P value \\
\hline $\begin{array}{c}\text { Male } \\
(\mathrm{N}=40)\end{array}$ & $\begin{array}{c}107.44 \\
\mathrm{SD} \pm 6.95\end{array}$ & $\begin{array}{c}104.63 \\
\mathrm{SD} \pm 6.41\end{array}$ & $107.44 \pm 6.95$ & $<0.001$ \\
\hline $\begin{array}{c}\text { Female } \\
(\mathrm{N}=35)\end{array}$ & $\begin{array}{c}91.65 \\
\mathrm{SD} \pm 7.03\end{array}$ & $\begin{array}{c}102.77 \\
\mathrm{SD} \pm 6.57 \%\end{array}$ & $91.65 \pm 7.03$ & $<0.001$ \\
\hline
\end{tabular}

Table 2. Sex-Wise Length (mm), Breadth (mm), Mean \pm SD, Minimum-Maximum, $P$ value 
Differences between length and breadth done by paired student's ' $t$ ' test and comparison between sex done by unpaired student's ' $t$ ' test was significant (Table 2).

Mean sacral index in male and female were $97.88 \pm 6.16 \%$ and $112.69 \pm 10.17 \%$ respectively.

Female has the greater sacral index than male $(\mathrm{P}<0.001)$.

\section{DISCUSSION}

In present study, mean sacral index is found to be higher than Indians of Tamilnadu and Andhra and of Bengal and lower than Australians and of white Americans and black
Americans and Haryana and UP region. In female, values is found to be more than Indians of Bengal and Tamilnadu and Andhra, but lower than Australians and Americans. Similarly, variations in sacral breadth and sacral index were also observed as shown in (Table 3).

These observations are in accordance with those of Davivongs in Australia's aborigines and Flander in AmericanBlacks.

Flander used univariate and multivariate analysis method for sex determination of sacrum.

\begin{tabular}{|c|c|c|c|c|c|c|c|c|}
\hline & & $\begin{array}{c}\text { Mean Male } \\
\text { Sacral Length }\end{array}$ & $\begin{array}{c}\text { Mean Male } \\
\text { Sacral } \\
\text { Breadth } \\
\end{array}$ & $\begin{array}{c}\text { No. of } \\
\text { Sacrum }\end{array}$ & $\begin{array}{l}\text { Mean Female } \\
\text { Sacral Length }\end{array}$ & $\begin{array}{c}\text { Mean Female } \\
\text { Sacral Breadth }\end{array}$ & $\begin{array}{l}\text { Mean Sacral } \\
\text { Index Male }\end{array}$ & $\begin{array}{l}\text { Mean Sacral } \\
\text { Index Female }\end{array}$ \\
\hline $\begin{array}{r}\text { Dav } \\
(1 \\
\text { Australia }\end{array}$ & $\begin{array}{l}\text { ivongs } \\
963)^{4} \\
\text { in Aborigine }\end{array}$ & $96.5 \pm 0.88$ & $88.1 \pm 0.687$ & 100 & $99.9 \pm 0.5$ & $101.2 \pm 0.51$ & $104.16 \pm 8.93$ & $115.49 \pm 10.39$ \\
\hline & $\begin{array}{c}\text { White } \\
\text { Americans }\end{array}$ & - & - & 100 & - & - & $106.49 \pm 10.4$ & $108.69 \pm 13.59$ \\
\hline$(1978)^{9}$ & $\begin{array}{c}\text { Black } \\
\text { Americans }\end{array}$ & - & - & 100 & - & - & $106.17 \pm 10.36$ & $112.35 \pm 11.03$ \\
\hline $\begin{array}{r}\text { Mis } \\
\text { et al } \\
\text { Agl }\end{array}$ & $\begin{array}{l}\text { hra SR } \\
(2003)^{1} \\
\text { a (UP) }\end{array}$ & $107.53 \pm 7.03$ & $90.58 \pm 4.42$ & 116 & $105.34 \pm 6.222$ & $105.16 \pm 6.322$ & $98.21 \pm 4.89$ & $117.84 \pm 7$ \\
\hline $\begin{array}{r}\mathrm{Ma} \\
\mathrm{MM} \\
\end{array}$ & $\begin{array}{l}\text { th SC10 } \\
(2006) \\
\end{array}$ & 117.00 & 104.20 & & 86.00 & $106.30 \mathrm{~mm}$ & $94.24 \%$ & $113.19 \%$ \\
\hline $\begin{array}{r}\text { Patel M } \\
\text { (G }\end{array}$ & $\begin{array}{l}\text { IM }(2006)^{7} \\
\text { ujrat) }\end{array}$ & - & - & 64 & - & - & $\begin{array}{c}90.5-106 \% \\
\text { Mean } 96.25 \%\end{array}$ & $\begin{array}{c}104.8-131 \% \\
\text { Mean } 113.25 \%\end{array}$ \\
\hline $\begin{array}{r}\text { Arora } \\
\quad(2 \\
(\mathrm{P} \\
\end{array}$ & $\begin{array}{l}\text { AK et al } \\
010)^{11} \\
\text { unjab) }\end{array}$ & $109.74 \pm 11.66$ & $91.22 \pm 6.348$ & 40 & $101.44 \pm 8.96$ & $114.13 \pm 9.67$ & $93.69 \pm 11.57$ & $125.35 \pm 11.47$ \\
\hline $\begin{array}{r}\text { Sach } \\
\text { al }(2 \\
(\mathrm{P}\end{array}$ & $\begin{array}{l}\text { deva K et } \\
2011)^{12} \\
\text { unjab) }\end{array}$ & $10.41 \pm 1.26$ & $91.8 \pm 0.71$ & 50 & $10.31 \pm 0.78$ & $10.1 \pm 0.7$ & $100.24 \pm 12.54$ & $111.14 \pm 14.6$ \\
\hline $\begin{array}{r}\text { Mazu } \\
\text { al }(2 \\
\text { (India }\end{array}$ & $\begin{array}{l}\text { mdar S et } \\
2012)^{13} \\
\text { n Bengal) }\end{array}$ & $100.8 \pm 11.5$ & $87.3 \pm 7.4$ & 250 & $96.3 \pm 7.4$ & $95.6 \pm 5.7$ & $94.9 \pm 4.8$ & $109.8 \pm 7.3$ \\
\hline $\begin{array}{r}\text { Ravich } \\
(2013)^{14} \\
\text { and }\end{array}$ & $\begin{array}{l}\text { andran D } \\
\text { (Tamilnadu } \\
\text { Andhra) }\end{array}$ & 97.8 & 93.7 & 123 & 90.96 & 92.91 & $96.32 \pm 5.40$ & $102.29 \pm 4.0$ \\
\hline $\begin{array}{r}\text { Bindra e } \\
\text { In } \\
\text { (Harya }\end{array}$ & $\begin{array}{l}\text { tal }(2015)^{15} \\
\text { dians } \\
\text { na Region) }\end{array}$ & 106.85 & 90.89 & 60 & 108.24 & 106.87 & 101.3 & 117.56 \\
\hline $\begin{array}{l}\text { Yadav } \mathrm{N} \\
\text { Indian }(\mathrm{N}\end{array}$ & $\begin{array}{l}\text { tah al }(2015)^{16} \\
\text { Iaharashtra) }\end{array}$ & $104.7 \pm 5.94$ & $102.93 \pm 4.83$ & 140 & $92.6 \pm 6.1$ & $104.77 \pm 6.48$ & $98.44 \pm 4.69$ & $113.23 \pm 5.61 \%$ \\
\hline $\begin{array}{l}\text { Present } \\
\text { (Central }\end{array}$ & $\begin{array}{l}\text { Study (2017) } \\
\text { Rajasthan) }\end{array}$ & 107.44 SD \pm 6.95 & $\begin{array}{c}104.63 \\
S D \pm 6.41\end{array}$ & 75 & 97.88 & $\begin{array}{c}102.77 \\
S D \pm 6.57 \%\end{array}$ & $\begin{array}{c}97.88 \\
\mathrm{SD} \pm 6.16 \%\end{array}$ & $\begin{array}{c}112.69 \\
\mathrm{SD} \pm 10.17 \%\end{array}$ \\
\hline
\end{tabular}

Table 3. Comparative Study of Sacral Index by Different Authors in Different Population

Mishra et al ${ }^{1}$ examined 116 adult human dry sacra (74 males and 42 females) of Agra region and showed that mean length was greater in male $(107.53 \pm 7.03 \mathrm{~mm})$ than female $(105.34 \pm 6.222)$, which was similar to the present study. Math ${ }^{10}$ described that ventral straight length in male was $117.00 \mathrm{~mm}$ and that for female was $86.00 \mathrm{~mm}$. Mean length of male sacra was significantly higher than in female, which was similar to the present study. The mean $( \pm S D)$ breadth of sacrum in present study in male and female was 107.44 SD \pm $6.95 \mathrm{~mm}$ and $102.77 \pm 6.57 \mathrm{~mm}$ respectively are similar to the findings of Arora. ${ }^{11}$ Our reading is higher than Davivong et $\mathrm{al}^{4}$ in Australian aborigine.

Math $^{10}$ described that width of sacrum in male was $104.20 \mathrm{~mm}$ and that for female was $106.30 \mathrm{~mm}$. He also described that sacrum with maximum length measuring 
above $117.00 \mathrm{~mm}$ is definitely a male and below $86.00 \mathrm{~mm}$ is definitely a female.

Arora ${ }^{11}$ examined sacra of Punjab region and showed that maximum breadth of male sacrum was $91.22 \pm 6.348 \mathrm{~mm}$ and in female was $114.13 \pm 9.67 \mathrm{~mm}$. The mean breadth of sacrum in male in present study was similar to the values reported by Math ${ }^{10}$ and almost equal to Yadav et al,16 but higher than Mishra et al, ${ }^{1}$ Mazumdar et al, ${ }^{13}$ Bindra et al ${ }^{14}$ and Ravichander et al. ${ }^{14}$

The mean sacral index in male and female in present study are $97.88 \pm 6.16 \%$ and $112.69 \pm 10.17 \%$ respectively. Female has the greater sacral index than male and the difference was statistically highly significant $(<0.001)$. Our study was similar to Patel, ${ }^{7}$ who had reported the range of sacral index for males as 90.5 - 106\% (Mean sacral index was $96.25 \%$ ) and in case of females, sacral index was 104.8 $131 \%$ (Mean sacral index was 113.25\%). Sacral index according to Davivong et $\mathrm{al}^{4}$ in Australian aborigine is higher in both male and female than present study.

Our present study is similar to Math, ${ }^{10}$ Arora et $\mathrm{al}^{7}$ and Mazumdar et $\mathrm{al}^{13}$ who had reported average value for sacral index in male were $94.24 \%$ and for females were $113.19 \%$ in Yadva $\mathrm{N}$ et al ${ }^{16}$ of Maharashtra, but lower than Sachdeva et $\mathrm{al}^{12}$ and Bindra et $\mathrm{al}^{15}$ in Haryana.

Flander ${ }^{12}$ reported the average sacral index in white males was 106.49 and in white female was 108.69. In blacks, he reported the average was 106.17 in males and 112.35 in females. Thus, from the above discussion, it is clear that the average sacral index varies among different populations.

Thus, present study clearly indicates the presence of racial and regional differences in sacrum, especially length parameters and sacral index methods can be used as an effective method of sex determination of sacrum.

\section{CONCLUSION}

Since sacrum is a part of the pelvic girdle with functional differences between the two sexes, sacrum is important for identification of sex of human skeletal system. Sexing of sacrum by sacral index method is relevant and significant. The average sacral index identified in the present study would be of use to forensic experts, anthropologists and anatomists of central part of Rajasthan. We recommend future studies with larger sample size. Such studies will also be useful to observe the changing trends if any in the metric measurement which is influenced by environmental, socioeconomic factors, physical stress and genetic factors.

\section{ACKNOWLEDGEMENT}

Author would like to thank the Department of Anatomy, Government Medical College, Kota for the support in conducting the present study. Author is also very thankful to all the scholars, whose articles are cited and references included in present manuscript. Authors would like to thank from the bottom of his heart to all the authors, editors and publishers of all the articles and books from where the literatures for this manuscript has been reviewed and discussed.

\section{REFERENCES}

[1] Mishra SR, Singh PJ, Agrawal AK, et al. Identification of sex of sacrum of Agra region. J Anat Soc India 2003;52(2):132-6.

[2] Sugar 0. How the sacrum got its name. JAMA 1987;257(15):2061-3.

[3] Standring S. Gray's anatomy the anatomical basis of clinical practice. Paris: Churchill Livingston 2008:7248.

[4] Davivongs V. The pelvic girdle of the Australian aborigines-sex difference and sex determination. Am J Phys Anthropol 1963;21:443-55.

[5] Krishan K. Anthropometry in forensic medicine and forensic science-'forensic anthropometry'. The Internet Journal of Forensic Science 2007;2(1):1-12.

[6] Cheng JS, Song JK. Anatomy of the sacrum. Neurosurg Focus 2003;15(2):1-9.

[7] Patel MM, Gupta BD, Singel TC. Sexing of sacrum by sacral index and kimura's base wing index. JIAFM 2005;27(1):5-9.

[8] Krogman WM, Iscan MY. The human skeleton in forensic medicine. $2^{\text {nd }}$ edn. Thomas CC, Springfield, Illinois, U.S.A. 1986:224-6.

[9] Flander LB. Univariate and multivariate methods for sexing the sacrum. Am J Phys Anthropol 1978;49(1):103-10.

[10] Math SC. Sexual dimorphism in sacrum. M.S. Rajiv Gandhi University of Health Sciences, Karnataka, Bangalore 2006:59-69.

[11] Arora KA, Gupta P, Mahajan S, et al. Significance of sacral index in estimation of sex in sacra of cadavers in Punjab. J Indian Acad Forensic Med 2010;32(2):104-7.

[12] Sachdeva K, Singla RK, Kalsey G, et al. Role of sacrum in sexual dimorphism-a morphometric study. J Indian Acad Forensic Med 2011;33(3):206-10.

[13] Mazumdar S, Ray A, Mazumdar A, et al. Sexual dimorphism and regional difference in size of sacrum: a study in Eastern India. Al Ameen J Med Sci 2012;5(3):298-307.

[14] Ravichandran D, Shanthi KC, Shankar K, et al. A study on sacral index in Tamil Nadu and Andhra Pradesh population of southern India. J Clin Diagn Res 2013;7(9):1833-4.

[15] Bindra GS, Mohan A. Sacral index: application in sex determination of sacrum. Int J Sci Stud 2015;2(10):7981.

[16] Yadav N, Saini K, Patil K. Determination of sex using dry adult human sacrum-a morphometric study. Int J Cur Res Rev 2015;7(3):22-8. 